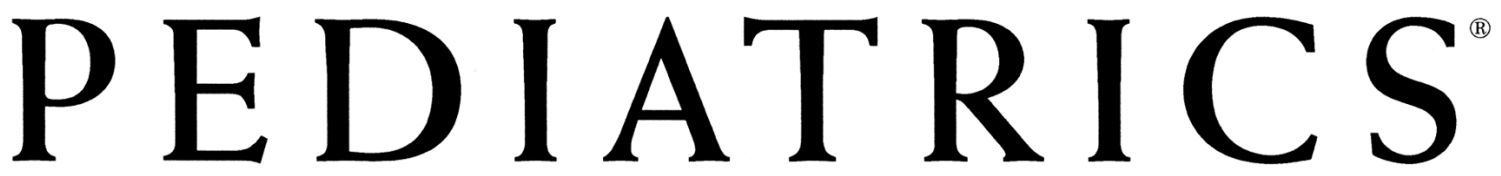

OFFICIAL JOURNAL OF THE AMERICAN ACADEMY OF PEDIATRICS

\title{
Endocrinologic Disorders and Optic Pathway Gliomas in Children With Neurofibromatosis Type 1
}

Marjon H. Cnossen, Esther N. Stam, Linda C. M. G. Cooiman, Huibert J. Simonsz, Hans Stroink, Arnold P. Oranje, Dicky J. J. Halley, Arja de Goede-Bolder, Martinus F. Niermeijer and Sabine M. P. F. de Muinck Keizer-Schrama

Pediatrics 1997;100;667

DOI: $10.1542 /$ peds.100.4.667

The online version of this article, along with updated information and services, is located on the World Wide Web at:

http://pediatrics.aappublications.org/content/100/4/667.full.html

PEDIATRICS is the official journal of the American Academy of Pediatrics. A monthly publication, it has been published continuously since 1948. PEDIATRICS is owned, published, and trademarked by the American Academy of Pediatrics, 141 Northwest Point Boulevard, Elk Grove Village, Illinois, 60007. Copyright (C) 1997 by the American Academy of Pediatrics. All rights reserved. Print ISSN: 0031-4005. Online ISSN: 1098-4275.

\section{American Academy of Pediatrics}

DEDICATED TO THE HEALTH OF ALL CHILDREN ${ }^{m}$ 


\title{
Endocrinologic Disorders and Optic Pathway Gliomas in Children With Neurofibromatosis Type 1
}

\author{
Marjon H. Cnossen, MD*‡; Esther N. Stam*; Linda C. M. G. Cooiman*; Huibert J. Simonsz, MD, PhD§; \\ Hans Stroink, MD\|; Arnold P. Oranje, MD, PhDII; Dicky J. J. Halley, PhD ; Arja de Goede-Bolder, MD*; \\ Martinus F. Niermeijer, MD, PhD $\ddagger$; and Sabine M. P. F. de Muinck Keizer-Schrama, MD, PhD\#
}

\begin{abstract}
Objective. To establish the prevalence of endocrinologic disorders in children with neurofibromatosis type 1 (NF1) and the relationship between these disorders and cerebral abnormalities on magnetic resonance imaging.

Design. A prospective follow-up study.

Setting. A multidisciplinary neurofibromatosis clinic.

Patients. A total of 122 children diagnosed with NF1 according to diagnostic criteria set by the National Institutes of Health.

Results. Central precocious puberty (CPP) was diagnosed in 3 children and growth hormone deficiency (GHD) in 3 children. Optic pathway gliomas were observed in 15 children; in 9 of the 15 cases, the optic chiasm was involved. Of the 3 children with CPP, only 1 showed a chiasma glioma on magnetic resonance imaging. In 1 case with GHD, an optic chiasm glioma was detected on neuroimaging. Two of the 9 children with an optic chiasm glioma presented with CPP or GHD.

Conclusions. It has been suggested that CPP in children with NF1 is found exclusively in the presence of a chiasma glioma. We conclude that chiasma glioma may not be obligatory in children with NF1 and CPP or GHD. Moreover, we report a prevalence of GHD in children with NF1 of $2.5 \%$, which has not been established earlier. Pediatrics 1997;100:667-670; neurofibromatosis type 1, endocrinologic disorder, central precocious puberty, growth hormone deficiency, optic pathway glioma.
\end{abstract}

ABBREVIATIONS. NF1, neurofibromatosis type 1; NIH, National Institutes of Health; CPP, central precocious puberty; GHD, growth hormone deficiency; VEP, visual evoked potentials; CT, computed tomography; MRI, magnetic resonance imaging; $\mathrm{SD}$, standard deviation; $\mathrm{GH}$, growth hormone; $\mathrm{LHRH}$, luteinizing hormone-releasing hormone.

$\mathrm{N}$ eurofibromatosis type 1 (NF1) is an autosomal-dominant disorder affecting 1 in 3300 individuals. Characteristic features are caféau-lait-colored spots, freckling in intertriginous regions, neurofibromas, and Lisch nodules (iris hamar-

From the Departments of *Pediatrics, ¥Clinical Genetics, §Ophthalmology, |Neurology, IIDermatology, and \#Pediatric Endocrinology, University Hospital Sophia/Dijkzigt, Erasmus University, Rotterdam, The Netherlands. Received for publication Dec 3, 1996; accepted Feb 26, 1997

Reprint requests to (M.H.C.) Department of Pediatrics, University Hospital Sophia/Dijkzigt, Erasmus University Rotterdam, Dr Molewaterplein 60, 3015 GJ Rotterdam, The Netherlands.

PEDIATRICS (ISSN 0031 4005). Copyright $@ 1997$ by the American Academy of Pediatrics. tomas). Diagnostic criteria have been established by National Institutes of Health (NIH). ${ }^{1}$

Endocrine disorders have been reported in $\sim 1 \%$ to $3 \%$ of all NF1 patients. In adults, pheochromocytoma is the most common disorder, presenting in $\sim 1 \%$ of NF1 patients. ${ }^{2}$ In children with NF1, central precocious puberty (CPP) is the most frequent endocrinopathy and is seen in 3\% of NF1 patients compared with $.06 \%$ in the general pediatric population. $.^{2-4} \mathrm{Al}-$ though various case reports have been published, the prevalence of growth hormone deficiency (GHD) in children with NF1 is unknown and is assessed in this paper.

Listernick et $\mathrm{al}^{5}$ reported that routine magnetic resonance neuroimaging in 176 children with NF1 revealed optic pathway gliomas in $33(19 \%)$. Almost half of these gliomas were asymptomatic. In particular, gliomas of the optic chiasm have been reported to cause endocrinologic disorders, especially CPP. ${ }^{6}$

In a prospective follow-up study in a multidisciplinary NF1 clinic, we analyzed the prevalence of endocrinologic disorders in children and the relationship between these disorders and cerebral abnormalities on neuroimaging.

\section{PATIENTS AND METHODS}

Since 1985, a multidisciplinary NF1 team at Sophia Children's University Hospital in Rotterdam (including a pediatrician, dermatologist, pediatric neurologist, ophthalmologist, and clinical geneticist) has evaluated children suspected of having NF1 according to NIH criteria. Besides periodic clinical evaluations, $x-$ rays of the cranium and the entire spine and a visual evoked potential (VEP) are performed at presentation. Computed tomography $(\mathrm{CT})$ scanning and/or magnetic resonance imaging (MRI) is initiated when indicated.

Before January 1995, 171 new cases were seen. NF1 was diagnosed in 122 children ( 58 girls, 64 boys). The average follow-up period in the NF1-affected group was 4.4 years (standard deviation $[S D]=4.1)$. The mean age of these children at last examination date was 9.9 years $(\mathrm{SD}=5.3)$. Still at risk for CPP were 16 of $58(28 \%)$ girls who were $<8$ years of age and 25 of $64(39 \%)$ boys who were $<9$ years of age at last examination date. Of the remaining 49 children, 17 remained suspect for NF1, having only one diagnostic criterion, other than a positive family history. In 32 children, the diagnosis of NF1 was rejected.

CPP was defined as the appearance of secondary sexual characteristics before the age of 8 years in girls and 9 years in boys. Secondary sexual characteristics included breast development of at least Tanner stage B2 in girls and genital development of at least Tanner stage G2 and a testicular volume of $\geq 4 \mathrm{~mL}$ in boys. ${ }^{7}$ In addition, increased growth velocity, accelerated bone maturation, and pubertal responses of plasma luteinizing hormone $(>10$ $\mathrm{mU} / \mathrm{L}$ ) during a standard luteinizing hormone-releasing hormone (LHRH) stimulation test were present in all cases. ${ }^{8,9}$ Pituitary 
gonadotropin response to LHRH was obtained after intravenous injection of $100 \mu \mathrm{g}$ of LHRH. Subsequently, serum samples were taken at 0,30 , and 60 minutes after injection. ${ }^{10}$

The diagnosis of GHD was based on a decreased height velocity over a period of at least 6 months or a decrease in height SD score of $>0.25 /$ year. ${ }^{11}$ In addition, maximum plasma growth hormone $(\mathrm{GH})$ peaks remained below $20 \mathrm{mU} / \mathrm{L}$ in at least two standard pharmacologic provocation tests (clonidine, arginine). After administration of $0.15 \mathrm{mg} / \mathrm{m}^{2}$ clonidine orally or $0.5 \mathrm{~g} / \mathrm{kg}$ body weight of arginine solution intravenously in 30 minutes, GH plasma values were measured at $0,30,60,90,120$, and 150 minutes for the clonidine test, and at $0,15,30,75,90$, and 120 minutes for the arginine test. Plasma GH was determined by a specific radioimmunoassay, using polyclonal antibodies after acid chromatography. ${ }^{12}$ Prepubertal girls were estrogen-primed from the age of 8 years and prepubertal boys from the age of 9 years. A plasma insulin-like growth factor 1 value of 2 SDs below the reference values for age supported a diagnosis of GHD. ${ }^{12}$ Other causes of decreased growth velocity were excluded.

Thyroid hormones were evaluated in all patients suspected of having an endocrinologic abnormality; no abnormalities were detected. Bone ages were analyzed according to Greulich and Pyle. ${ }^{12 a}$ When bone age and chronologic age differed by $>1$ year, bone age was considered divergent.

In our population, CT and MRI of the brain were performed only on indication. Indications included endocrinologic disorders; ophthalmologic abnormalities such as optic atrophy, a relative afferent pupillary defect, an abnormal Ishihara color vision test, or an abnormal VEP; mental retardation; and various other neurologic abnormalities. In all patients suspected of having an optic pathway glioma, a special protocol for the detection of these gliomas was used. ${ }^{13}$ All patients with an endocrinologic disorder were evaluated by MRI.

CPP patients were treated with the LHRH analogue Triptoreline (Ferring, Hoofddorp, the Netherlands), a depot preparation, once every 4 weeks intramuscularly. In GHD patients, treatment was initiated with recombinant human GH.

Children who developed endocrinologic abnormalities secondary to cranial irradiation for a progressive optic pathway glioma or malignancy were excluded from this study.

The study protocol was approved by the medical ethics committee of the Medical Faculty and the University Hospital Sophia/ Dijkzigt.

Data were analyzed using Dbase IV (Ashton-Tate, Amsterdam, the Netherlands) and SPSS (Statistical Products and Services Inc, Chicago, IL).

\section{RESULTS}

Endocrinologic disorders were diagnosed in 6 of the 122 children $(5.0 \%$; 95\% CI: $0.3 \%-9.7 \%)$, children with definite NF1. All patients were boys. CPP was diagnosed in $3(2.5 \%)$ of the 122 children (Table 1$)$. Mean age at diagnosis was 7.3 years. GHD was detected in $3(2.5 \%)$ of the 122 children (Table 1$)$. The mean age at diagnosis was 9 years. In 5 of the 6 children, NF1 was also diagnosed in one of the parents (3 mothers, 2 fathers).

In children diagnosed with CPP, a chiasma glioma was seen on MRI in one child (patient A). Patients B and $C$ showed no optic pathway glioma on MRI and had normal VEP, ophthalmologic, and neurologic examinations (Table 1). Furthermore, a chiasma glioma was observed in one child (patient D) diagnosed with GHD (Table 1).

Although no routine neuroimaging studies were performed, optic pathway gliomas were reported in 15 of 122 children with NF1 (12.3\%; 95\% CI: 6.5\%$18.1 \%) ; 6$ of the $15(40 \%)$ were located in the optic nerve and in 9 of the $15(60 \%)$, the optic chiasm was involved. In 5 of the 15 (33.3\%) children with an optic pathway glioma, no ophthalmologic abnormalities were observed after visual examinations and funduscopy; in 14 of the 15 (93.3\%) VEPs were abnormal. Endocrinologic disorders developed in 2 of the 9 children (22.2\%; 95\% CI: $10.2 \%-34.2 \%)$ with an optic chiasm glioma; no endocrine disorders were seen in children with an optic nerve glioma.

In total, 3 of 15 children $(20 \%)$ were treated with radiotherapy for a progressive optic pathway glioma (mean age, 9.7 years); 2 of the $3(66.6 \%)$ went on to

TABLE 1. Diagnosis of CPP and GHD in Children With NF1

\begin{tabular}{|c|c|c|c|}
\hline \multirow[t]{2}{*}{$\mathrm{CPP}$} & \multicolumn{3}{|c|}{ Patient } \\
\hline & A & B & C \\
\hline Optic pathway glioma* & Optic nerve and chiasm & - & - \\
\hline Ophthalmologic investigationt & $\mathrm{A}$ & $\mathrm{N}$ & $\mathrm{N}$ \\
\hline Sex & $\mathrm{m}$ & $\mathrm{m}$ & $\mathrm{m}$ \\
\hline Age at diagnosis NF1 (y) & 6.2 & 7.5 & 4.8 \\
\hline Age at presentation of secondary sexual characteristics (y) & 8.5 & 7.5 & 7.6 \\
\hline Increased growth velocity & + & + & + \\
\hline Accelerated bone maturation & + & + & + \\
\hline \multirow[t]{2}{*}{$\begin{array}{l}\text { Maximal LH response to LHRH stimulation }(100 \mathrm{mU} / \mathrm{L}, \mathrm{iv}) \\
\text { (prepubertal response }<10 \mathrm{mU} / \mathrm{L})\end{array}$} & 18.7 & 53.0 & 14.1 \\
\hline & $\mathrm{D}$ & $\mathrm{E}$ & $\mathrm{F}$ \\
\hline Optic pathway glioma* & Optic chiasm & - & - \\
\hline Ophthalmologic investigationt & A & Af & $\mathrm{N}$ \\
\hline Sex & $\mathrm{m}$ & $\mathrm{m}$ & $\mathrm{m}$ \\
\hline Age at diagnosis NF1 (y) & 5.0 & 2.7 & 5.0 \\
\hline Age at diagnosis GHD (y) & 8.6 & 11.3 & 7.0 \\
\hline Progressive deviation from growth curve & + & + & + \\
\hline Delayed bone maturation & + & + & + \\
\hline \multicolumn{4}{|l|}{ Maximum plasma GH value after provocation (mU/L) } \\
\hline Arginine test (normal: $>20 \mathrm{mU} / \mathrm{L}$ ) & 11 & 8.5 & 13 \\
\hline Clonidine test (normal: $>20$ mU/L) & 15 & 5.5 & 15 \\
\hline Plasma IGF-1 $(<-2 \mathrm{SD})$ & + & + & + \\
\hline
\end{tabular}

\footnotetext{
* All patients were screened by MRI, using a special protocol for detection of optic gliomas.

+ Vision, fundoscopy, visual field examination.

$\ddagger$ Hydrocephalus resulting from aqueduct stenosis caused papilloedema, which disappeared after treatment for hydrocephalus.

+ Indicates present; -, absent; N, normal; A, abnormal; m, male.
} 
develop GHD (patients $\mathrm{G}$ and $\mathrm{H}$ ), although patient $\mathrm{H}$ developed this complication after the follow-up period. In 1 other child (patient I), both GHD and CPP developed after radiotherapy of the cranium for an astrocytoma. These 3 children were not included in this study.

\section{DISCUSSION}

The prevalence of GHD in children with NF1 was $2.5 \%$, significantly higher than the $0.03 \%$ observed in the general pediatric population. ${ }^{14}$ In 1 of the 3 children with GHD, a chiasma glioma was detected; 1 of the $9(11.1 \%)$ children with a chiasma glioma presented with GHD. In our 3 cases, no growth of neurofibromas that could be ascribed to GH therapy was observed during clinical follow-up.

In our study, the prevalence of CPP is similar to the $3 \%$ observed by Habiby et $\mathrm{al}^{6}$ (Table 2). In contrast, we did not find evidence that optic chiasm glioma is a prerequisite for CPP, because only one of three children with CPP had an optic chiasm glioma at the time of diagnosis. This is the first observation demonstrating that a chiasma glioma can be absent in the presence of CPP, using MRI.

Strikingly, in our study, all endocrinologic disorders were observed in boys. In the literature, CPP is reported 8 times more often in girls than in boys and is sporadic and idiopathic in most cases. ${ }^{15}$ However, underlying organic disorders are more commonly discovered in male patients. Habiby et $\mathrm{al}^{6}$ found a female:male ratio of 2:5 in children with NF1 and CPP, as opposed to a female:male ratio of 22:11 in children with an optic pathway glioma. ${ }^{4}$ It appears that being a male with NF1 somehow predisposes one to CPP without an apparent explanation.

Saxena ${ }^{16}$ was the first to report precocious puberty as well as marked growth retardation in children with NF1. Various case reports published later on endocrine manifestations in NF1 ${ }^{17-20}$ concerned primarily CPP (Table 2), not GHD. Comparison of the studies is difficult because of the lack of clinical data as well as the fact that diagnostic criteria for NF1 were only defined by NIH in 1987. In addition, detection of optic pathway glioma with neuroimaging became more sensitive with the introduction of MRI. Generally, it was thought that all endocrinologic disorders in NF1 could be attributed to central nervous system tumors, such as chiasmal optic gliomas, compromising hypothalamic and pituitary function., ${ }^{2,21} \mathrm{In}$ a study comparing the clinical manifestations and natural history of optic pathway gliomas in children with NF1 compared with children without NF1, Listernick et $\mathrm{al}^{22}$ reported CPP in 5 of 17 children with an optic glioma and NF1, in contrast to no cases of CPP in a group of children with an optic pathway glioma and no features of NF1. The latter group appears predisposed toward endocrinologic complications, because chiasmal involvement was significantly more common. This seems to suggest an association between CPP and NF1 itself, which cannot be attributed solely to the presence of a chiasma glioma. Our data support this association.

Possible causal mechanisms may be cerebral abnormalities still undetected at a neuroimaging level, such as slow-growing hamartomas. In 2 patients with CPP and 1 patient with GHD studied by T2weighted MRI of the brain, high-signal-intensity foci were observed in the brainstem and supratentorial regions of the brain. These white matter lesions are common in children with NF1 and frequently increase in size or number, later resolving as the children get older. ${ }^{23}$ They are, however, not likely to be correlated with the development of CPP or GHD, because they are classically localized outside the sellar and suprasellar regions of the brain. Another possible explanation could be abnormalities at a cellular level. The latter is supported by current evidence that suggests that neurofibromin, the protein encoded by the NF1 gene, is part of a signal transduction chain extending from extracellular signals to transcriptional regulation in the nucleus. ${ }^{24}$

As a university clinic, we may examine more severe cases than generally seen in other hospitals. However, all but one case presented during followup. In contrast, the last child was referred with enlarged testes and pubic hair at 8 years of age. The high number of familial cases of NF1 observed in this

TABLE 2. Studies on Endocrine Manifestations of NF1

\begin{tabular}{|c|c|c|c|c|}
\hline $\begin{array}{c}\text { Author/Reference } \\
\text { (Year) }\end{array}$ & Neuroimaging Technique & $\begin{array}{l}\text { Number of } \\
\text { Children }\end{array}$ & Reason for Referral & Results \\
\hline Saxena/16 (1970) & $\begin{array}{l}\text { PEG } \\
\text { X-ray skull }\end{array}$ & 5 & $\begin{array}{l}\text { Growth/endocrine } \\
\text { disorders }\end{array}$ & NF1, intracranial mass in $1 / 5$ patients \\
\hline Tertsch/17 (1979) & $\begin{array}{l}\text { PEG } \\
\text { X-ray skull/optic foramina }\end{array}$ & 1 & Premature menstruation & NF1, chiasma glioma \\
\hline Iraci/18 (1980) & $\begin{array}{l}\text { PEG } \\
\text { X-ray skull/optic foramina }\end{array}$ & 24 & OPG & $3 / 24(12.5 \%)$ children OPG develop CPP \\
\hline Buonaguidi/19 (1982) & $\begin{array}{l}\text { PEG } \\
\text { CT }\end{array}$ & 4 & $\mathrm{CPP}$ & $1 / 4$ NF1 and OPG \\
\hline Laue/20 (1985) & $\mathrm{CT}$ & 7 & $\mathrm{CPP}+\mathrm{OPG}$ & $4 / 7$ children had NF1 \\
\hline Habiby / 6 (1995) & $\begin{array}{l}\text { MRI } \\
\text { CT }\end{array}$ & 219 & NF1 & $\begin{array}{l}\text { 7/219 (3\%) CPP, all chiasma glioma } \\
7 / 18(39 \%) \text { patients with chiasma } \\
\text { glioma developed CPP }\end{array}$ \\
\hline Cnossen et al (1997) & MRI & 122 & NF1 & $\begin{array}{l}\text { 3/122 (2.5\%) CPP, } 1 / 3 \text { chiasma glioma } \\
3 / 122(2.5 \%) \text { GHD, } 1 / 3 \text { chiasma glioma } \\
2 / 9(11 \%) \text { patients with chiasma glioma } \\
\text { developed CPP or GHD }\end{array}$ \\
\hline
\end{tabular}

PEG indicates pneumoencephalogram; OPG, optic pathway glioma. 
group of children may be attributable to an ascertainment bias, although approximately half of the NF1 patients examined were familial cases and half were sporadic cases. The disease was inherited from both mothers and fathers.

In conclusion, CPP and GHD are important complications in children with NF1. Although a glioma of the optic chiasm is often encountered in these patients, CPP and GHD also appear to develop in the absence of an optic chiasm glioma. Diagnostic follow-up is essential in children with NF1, because premature manifestations of puberty and deviations from the growth curve may be recognized. Subsequently, early treatment with LHRH analogues or recombinant human $\mathrm{GH}$, respectively, can be initiated with possible attainment of target height. Continuous monitoring will also help to establish any possible side effects of these interventions.

\section{ACKNOWLEDGMENTS}

We thank our patients and their parents for their cooperation. We also thank A.M.W. van den Ouweland for critical reading of the manuscript, S.G.F. Robben and H.L.J. Tanghe for evaluating the CT and MRI scans, and C.M. van Duijn for her advice with regard to the NF1 data base system.

\section{REFERENCES}

1. National Institute of Health Consensus Development Conference. Neurofibromatosis conference statement. Arch Neurol. 1988;45:575-578

2. Huson SM, Hughes RAC. The Neurofibromatoses: A Pathogenetic and Clinical Overview. London, UK: Chapman and Hall; 1994

3. Marshall WA, Tanner JM. Variations in pattern of pubertal changes in girls. Arch Dis Child. 1969;44:291-303

4. Marshall WA, Tanner JM. Variations in the pattern of pubertal changes in boys. Arch Dis Child. 1970;45:13-23

5. Listernick R, Charrow J, Greenwald M, Mets M. Natural history of optic pathway tumors in children with neurofibromatosis type 1: a longitudinal study. J Pediatr. 1994;125:63-66

6. Habiby R, Silverman B, Listernick R, Charrow J. Precocious puberty in children with neurofibromatosis type 1. J Pediatr. 1995;126:364-367

7. Brook CGD. Precocious puberty. Clin Endocrinol. 1995;42:647-650

8. Dean HJ, Winter JSD. Abnormalities of pubertal development. In: Collu R, Ducharme JR, Guyda HJ, eds. Pediatric Endocrinology. 2nd ed. New York, NY: Raven Press Ltd; 1989
9. Thomas CMG, Segers MFG. Measurement of serum hLH: hCG interference evaluated for two hLH-specific IRMA kits. Clin Chem. 1988;34: 768

10. Ranke MB, ed. Functional Endocrinologic Diagnostics in Children and Adolescents. Mannheim, Germany: Verlag; 1992

11. Rosenfeld RG, Albertson-Wikland K, Cassorla F, et al. Diagnostic controversy: the diagnosis of childhood growth hormone deficiency revisited. J Clin Endocrinol Metab. 1995;80:1532-1540

12. Hokken-Koelega ACS, Hackeng WHL, Stijnen T, Wit JM, de Muinck Keizer-Schrama SMPF, Drop SLS. Twenty-four hour plasma growth hormone $(\mathrm{GH})$ profiles, urinary $\mathrm{GH}$ secretion and plasma insulin-like growth factor-I and \#II levels in prepubertal children with chronic renal insufficiency and severe growth retardation. J Clin Endocrinol Metab. 1990;71:688-695

12a.Greulich WW, Pyle SI. Radiographic Atlas of Skeletal Development of the Hand and Wrist. 2nd ed. London, England: Oxford University Press; 1959

13. Robben SGF, Oostdijk W, Drop SLS, Tanghe HLJ, Vielvoye GJ, Meradji M. Idiopathic isosexual central precocious puberty: magnetic resonance findings in 30 patients. Br J Radiol. 1995;68:34-38

14. Lindsay R, Feldkamp M, Harris D, Robertson J, Rallison M. Utah Growth Study: growth standards and the prevalence of growth hormone deficiency. J Pediatr. 1994;125:29-35

15. Lifshitz F, ed. Pediatric Endocrinology: A Clinical Guide. New York, NY: Marcel Dekker, Inc; 1990:349

16. Saxena KM. Endocrine manifestations of neurofibromatosis in children. Am J Dis Child. 1970;120:265-271

17. Tertsch D, Schön R, Ulrich FE, Alexander H, Herter U. Pubertas praecox in neurofibromatosis of the optic chiasma. Acta Neurochir. 1979; 28(suppl):413-415

18. Iraci G, Gerosa M, Scanarini M, et al. Anterior optic gliomas with precocious or pseudoprecocious puberty. Child's Brain. 1980;7:314-324

19. Buonaguidi R, Ferdeghini M, Leoncini R, Tusini G. Hypothalamopituitary function in four cases of true precocious puberty. Child's Brain. 1982;9:211-221

20. Laue L, Comite F, Hench K, Loriaux L, Cutler GB, Hirsch Pescovitz O. Precocious puberty associated with neurofibromatosis and optic gliomas. Am J Dis Child. 1985;139:1097-1000

21. Riccardi VM, ed. Neurofibromatosis: Phenotype, Natural history, and Pathogenesis. Baltimore, MD: John Hopkins University Press; 1992:191-192

22. Listernick R, Darling C, Greenwald M, Strauss L, Charrow J. Optic pathway tumors in children: the effect of neurofibromatosis type 1 on clinical manifestations and natural history. I Pediatr. 1995;127:718-722

23. DiPaolo DP, Zimmerman RA, Rorke LB, Zackai EH, Bilaniuk LT, Yachnis AT. Neurofibromatosis type 1: pathologic substrate of highsignal-intensity foci in the brain. Radiology. 1995;195:721-724

24. Marshall M. Interactions between Ras and Raf: key regulatory proteins in cellular transformation. Mol Reprod Dev. 1995;42:493-499 


\section{Endocrinologic Disorders and Optic Pathway Gliomas in Children With Neurofibromatosis Type 1}

Marjon H. Cnossen, Esther N. Stam, Linda C. M. G. Cooiman, Huibert J. Simonsz, Hans Stroink, Arnold P. Oranje, Dicky J. J. Halley, Arja de Goede-Bolder, Martinus F. Niermeijer and Sabine M. P. F. de Muinck Keizer-Schrama

Pediatrics 1997;100;667

DOL: $10.1542 /$ peds.100.4.667

\section{Updated Information \& Services}

\section{References}

Citations

\section{Subspecialty Collections}

Permissions \& Licensing

Reprints including high resolution figures, can be found at: http://pediatrics.aappublications.org/content/100/4/667.full.ht $\mathrm{ml}$

This article cites 21 articles, 7 of which can be accessed free at:

http://pediatrics.aappublications.org/content/100/4/667.full.ht ml\#ref-list-1

This article has been cited by 9 HighWire-hosted articles: http://pediatrics.aappublications.org/content/100/4/667.full.ht ml\#related-urls

This article, along with others on similar topics, appears in the following collection(s):

\section{Genetics \& Dysmorphology}

http://pediatrics.aappublications.org/cgi/collection/genetics_a nd_dysmorphology

Information about reproducing this article in parts (figures, tables) or in its entirety can be found online at:

http://pediatrics.aappublications.org/site/misc/Permissions.xht $\mathrm{ml}$

Information about ordering reprints can be found online: http://pediatrics.aappublications.org/site/misc/reprints.xhtml

PEDIATRICS is the official journal of the American Academy of Pediatrics. A monthly publication, it has been published continuously since 1948. PEDIATRICS is owned, published, and trademarked by the American Academy of Pediatrics, 141 Northwest Point Boulevard, Elk Grove Village, Illinois, 60007. Copyright (@ 1997 by the American Academy of Pediatrics. All rights reserved. Print ISSN: 0031-4005. Online ISSN: 1098-4275.

\section{American Academy of Pediatrics}

DEDICATED TO THE HEALTH OF ALL CHILDREN ${ }^{m}$ 